\title{
NOTE ON THE ABBREVIATIONS IN THE TEXT
}

का

凹istorians of the classical world depend on a wide variety of evidence 1 in addition to the texts that have come down to us through the manuscript tradition. Many authors are known to us only through quotations in later authors. We call these quotations 'fragments', so the abbreviation Fr. that appears in the text will be referring to the quotation in an edition of the fragments of an author only known in this way. We also use collections of documents preserved on non-perishable materials (inscriptions) or papyri. The abbreviations for these works that appear in the text appear below, with explanation of what these collections mean.

AE L'Année épigraphique (the annual publication of recent discoveries of inscriptions)

FGrH F. Jacoby et al., Die Fragmente der griechischen Historiker (Leiden, 1926-9)

FRH T. Cornell, Fragments of the Roman Historians (Oxford, 2013)

GC J. H. Oliver, Greek Constitutions of Early Roman Emperors from Inscriptions and Papyri, Memoirs of the American Philosophical Society n. 178 (Philadelphia, 1989)

ILLRP A. Degrassi, Inscriptiones Latinae Liberae Rei Publicae (Latin Inscriptions of the Free Republic) (Göttingen, 1957)

ILS H. Dessau, Inscriptiones Latinae Selectae (Select Latin Inscriptions) (Berlin, I892-1916) 
RDGE R. K. Sherk, Roman Documents from the Greek East (Baltimore, 1969)

RGDA Res Gestae Divi Augusti (The deeds of the divine Augustus) with A. E. Cooley, Res Gestae Divi Augusti: Text, Translation, and Commentary (Cambridge, 2009)

RS M. H. Crawford, 'Roman Statutes', Bulletin of the Institute of Classical Studies Supplement 65 (London, 1996)

SCP Senatus Consultum Pisonianum (D.S. Potter and C. Damon, 'The Senatus Consultum de Cn. Pisone patre', The American Journal of Philology 120 (1999): 13-42)

SVA H. Bengston, ed., Die Staatsverträge des Altertums vol. 3 (Munich, 1975) (an invaluable compendium of evidence for treaties)

WT Writing tablet from R. S. O. Tomlin, ed., 'Roman London's First Voices: Writing Tablets from the Bloomberg Excavations, 2010-14', Museum of London Archaeology Monograph Series 72 (London, 2016) 



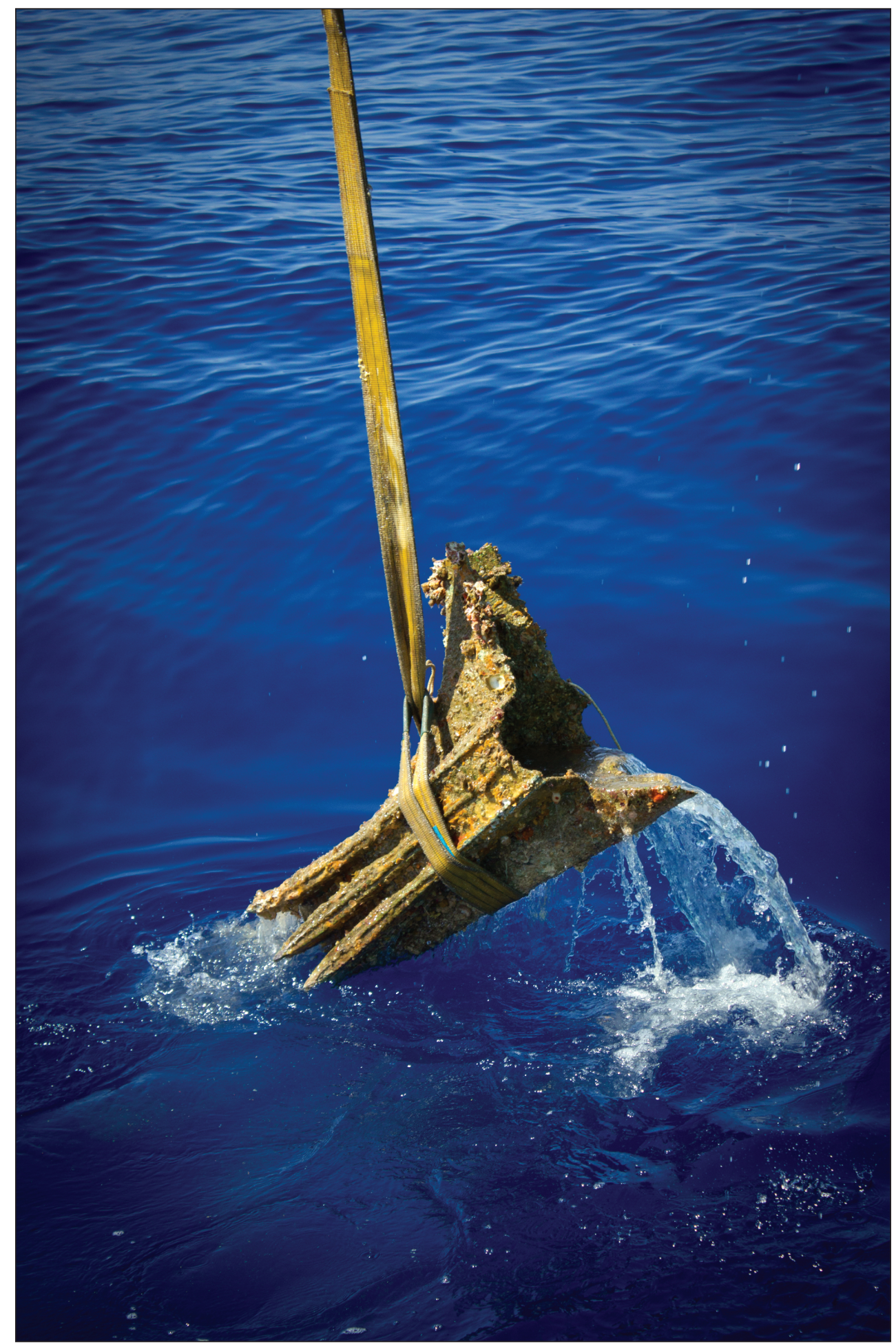

I. Archaeology constantly renews our understanding of antiquity. This is one of the rams from the floor of the sea off the Egadi Islands that has reshaped our understanding of naval conflict in the first war between Rome and Carthage (see p. 24). 


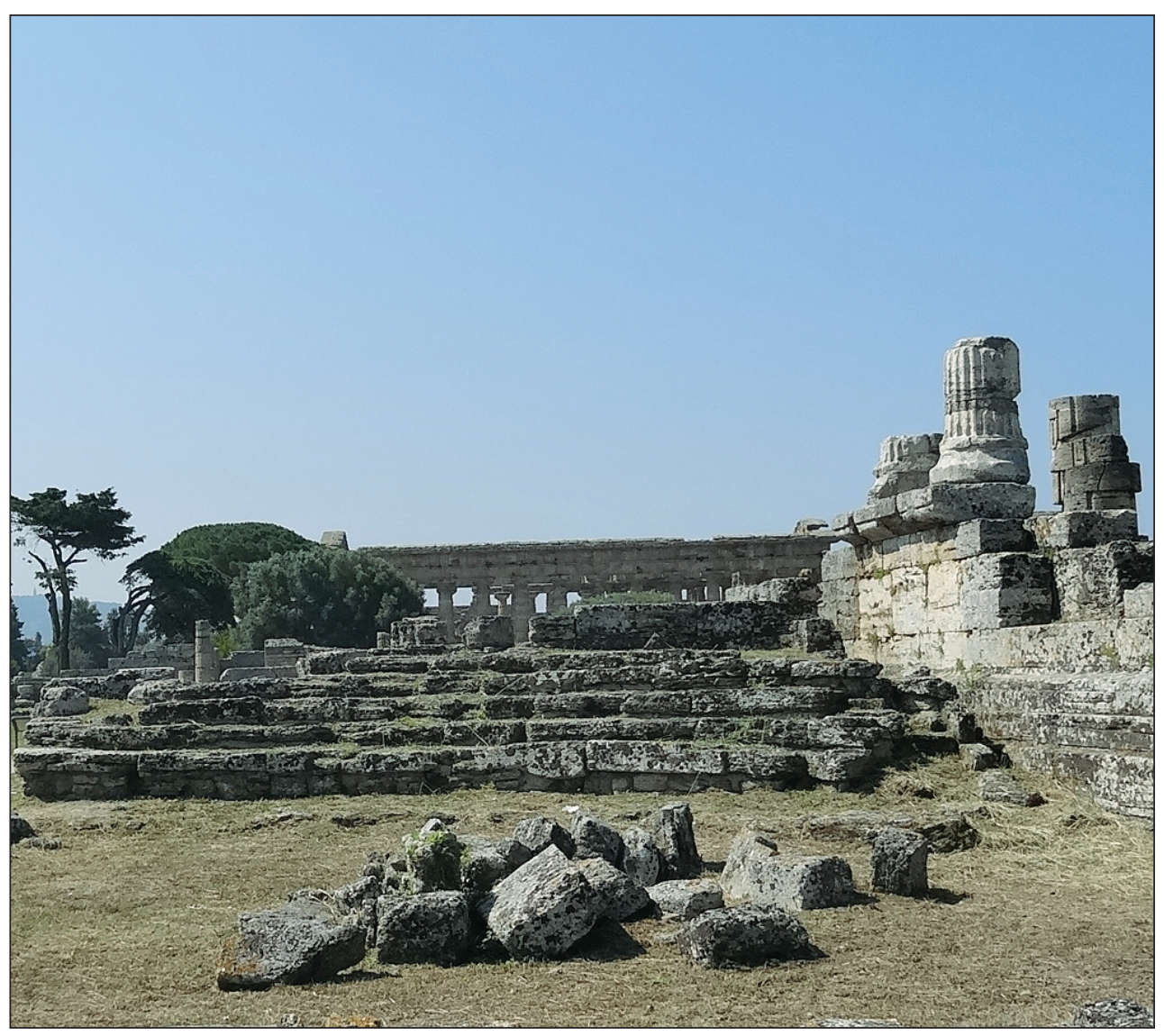

2. A view of the very Greek Athena temple at Paestum from the very Romanstyle Curia (Senate House) in the Roman-style Forum (p.36).

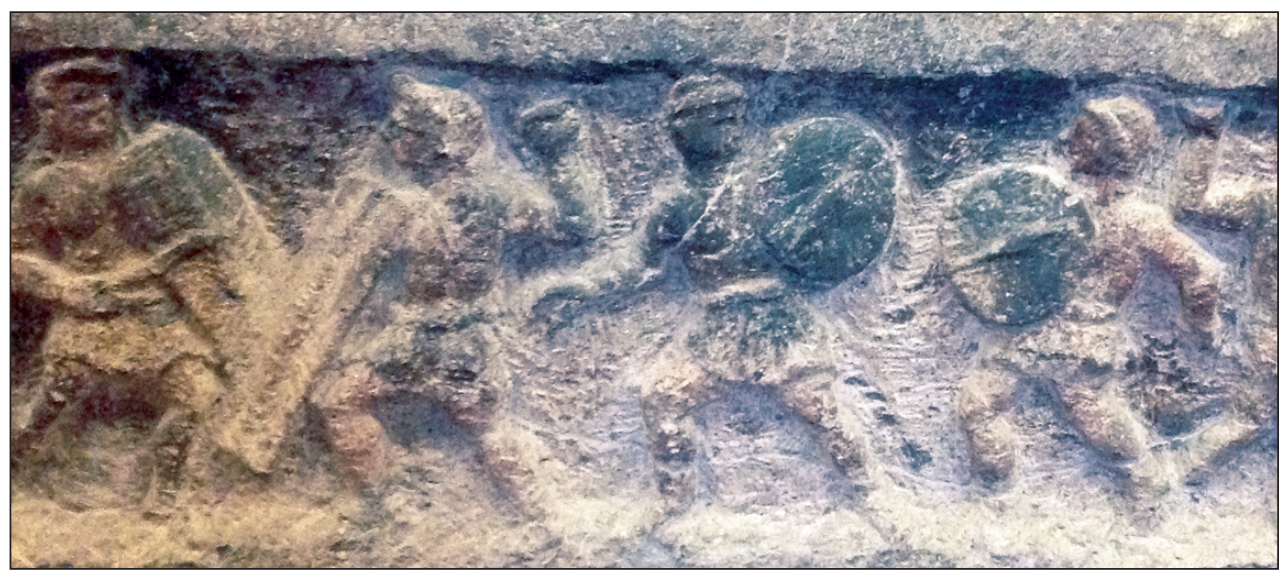

3. A relieffrom Tarquinia showing a battle between local troops and Gauls. This image of thirdcentury warriors underscores the community of interest that bound Etruscan states to Rome. 


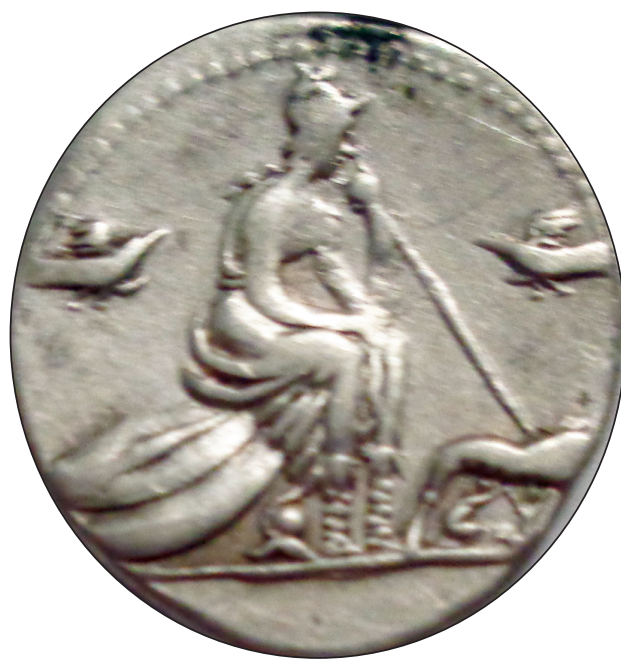

4. The goddess Roma observes the founding of Rome. The image of the city goddess looks out at the myth of Romulus and Remus and the augury that accompanied the city foundation. The coin seems to echo Ennius' account of the foundation of Rome (

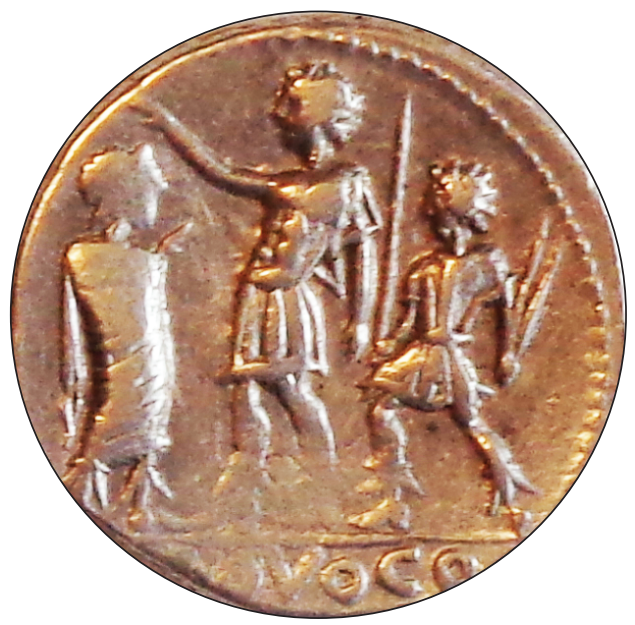

5. This coin commemorates the passage of the lex Porcia of $I 9 g$ BC by an ancestor of the official who minted this coin in IIO/g BC. The lex Porcia extended the right of appeal or provocatio to Roman citizens in the provinces. Here a soldier invokes the right of appeal against magistrate who stands to the left with his lictor on the right - the verb provoco 'I appeal' appears below the soldier's feet. Provocatio would be central to political discussions in the second to first centuries (p. 134, 196).

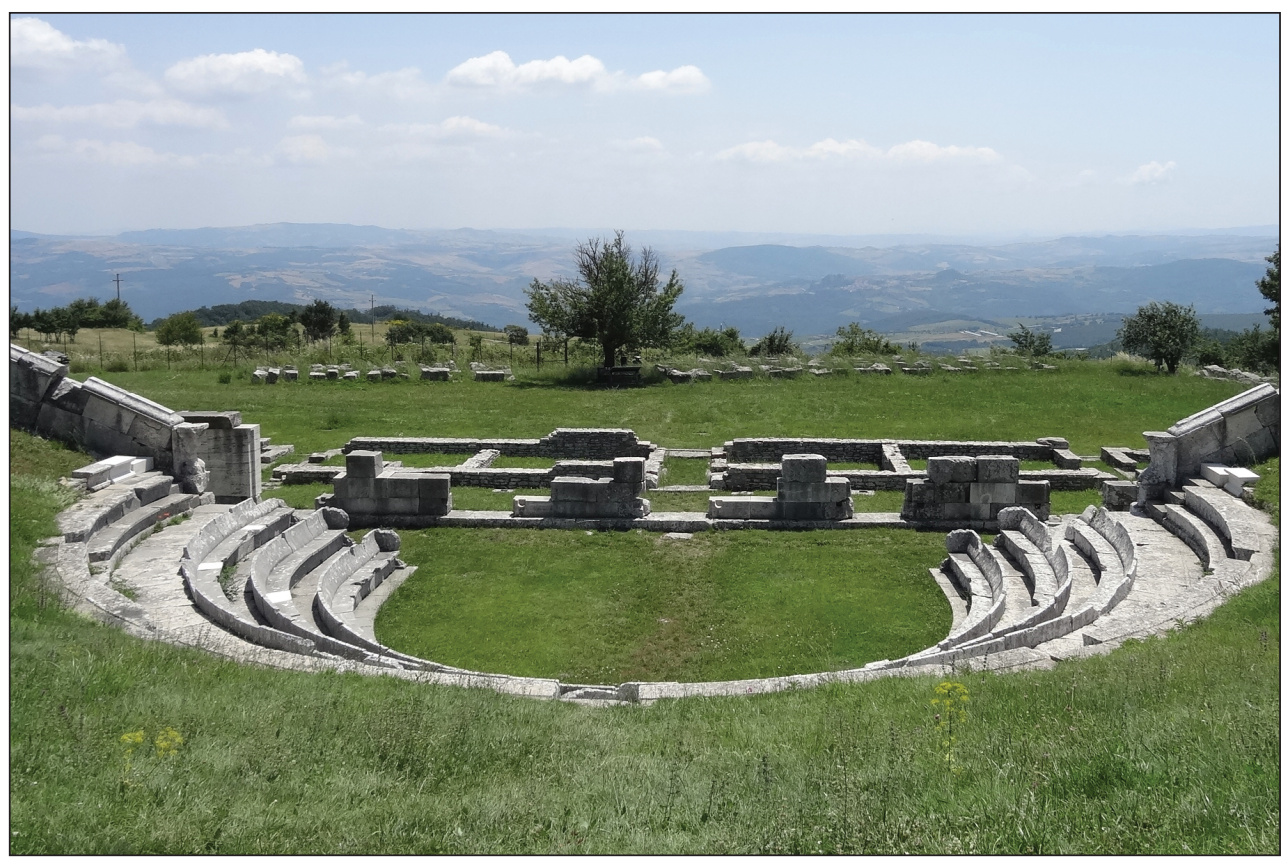

6. The theatre built by Statius Clarus at Pietrabondante (p. Is2). 


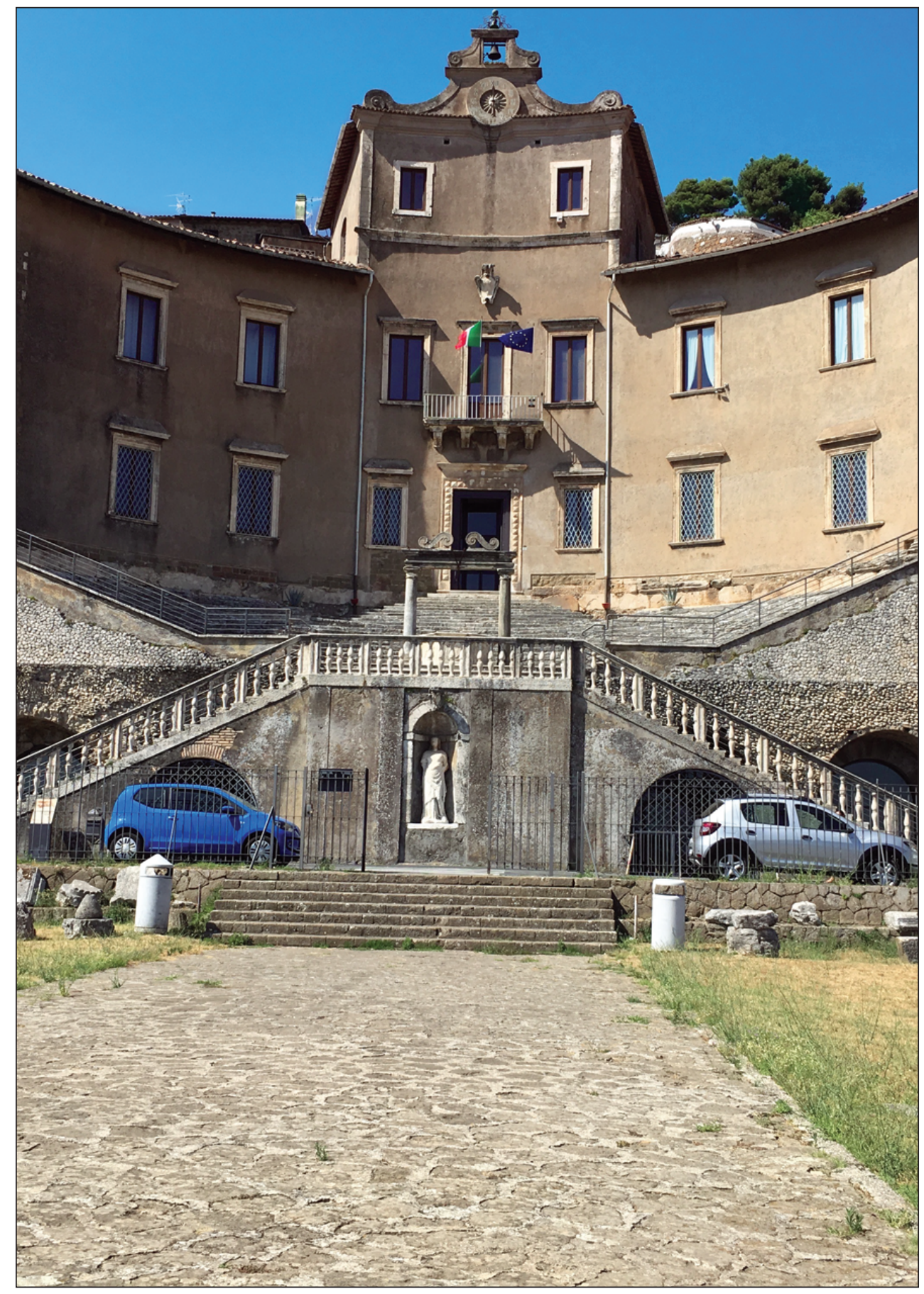

7. The site of the temple of Fortuna Primigenia at Praeneste. The temple was incorporated into the Palazzo Colonna Barbarini, but the meeting area that was attached to the site is visible in this picture (p. II4). 


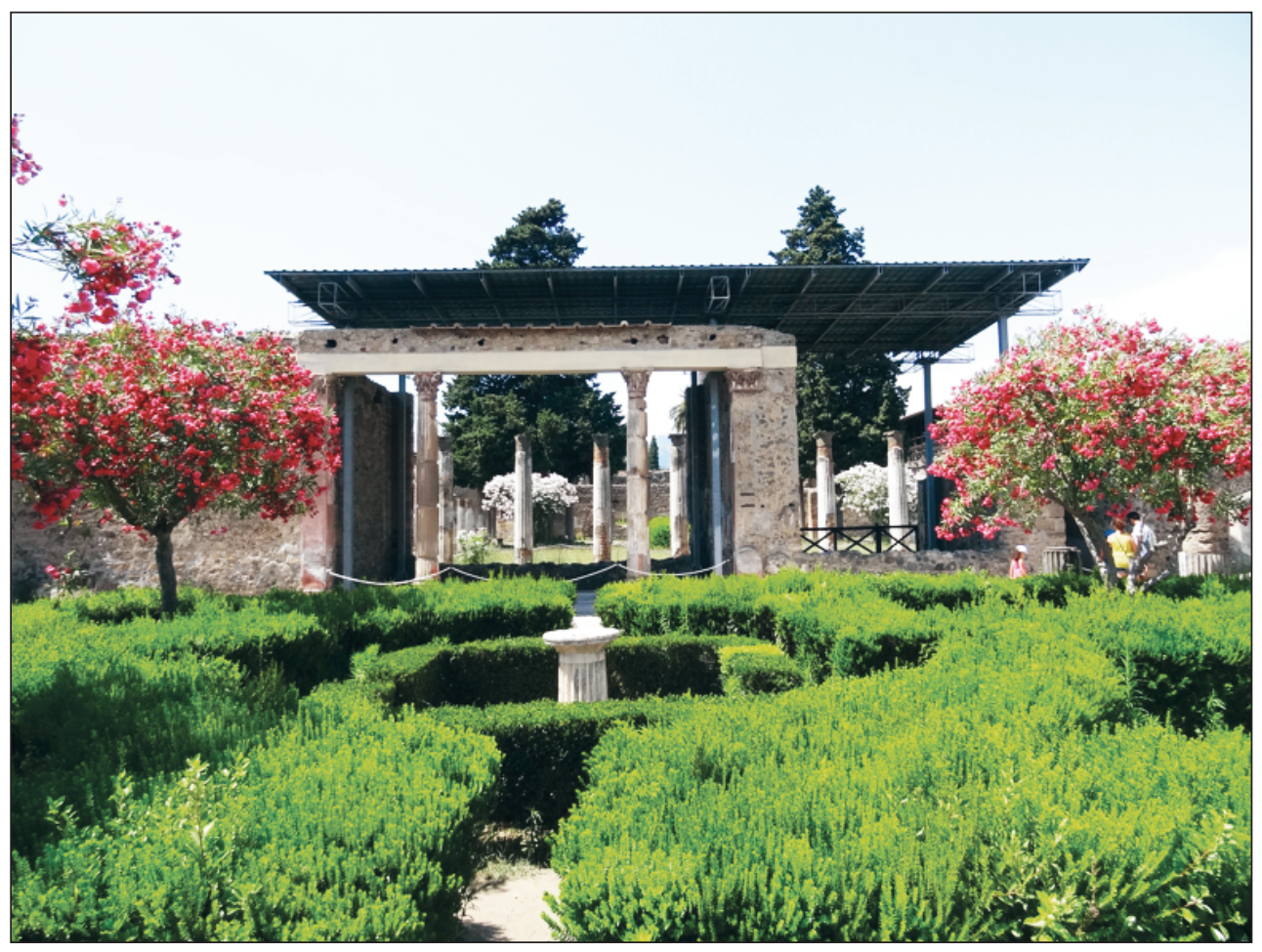

8. The garden of the vast House of the Faun at Pompeii. A mosaic (now in the Museo Archeologico Nazionale di Napoli) depicting Alexander the Great was once located in the structure in the middle of this picture (p. I53).

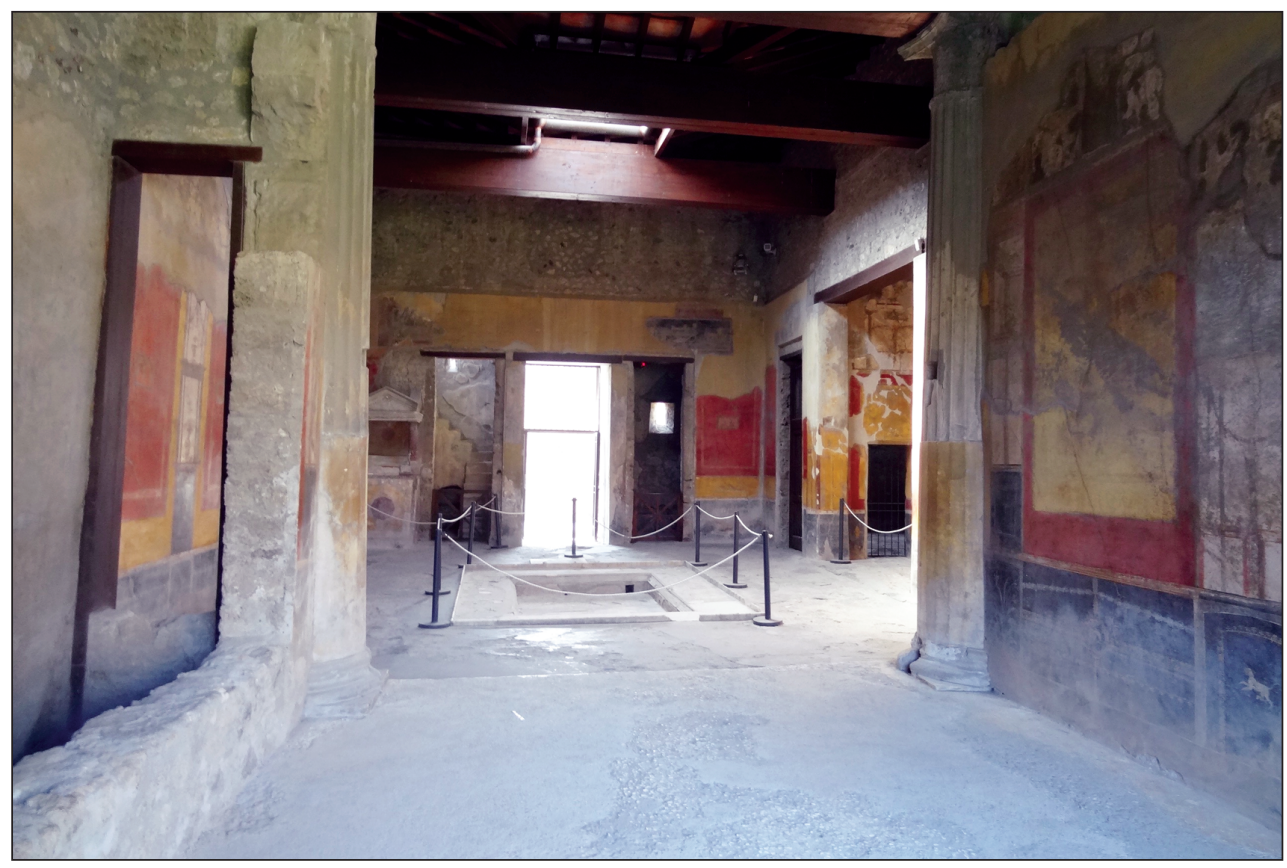

9. The spacious interior of the House of Menander at Pompeii looking out towards the peristyle court and garden. 


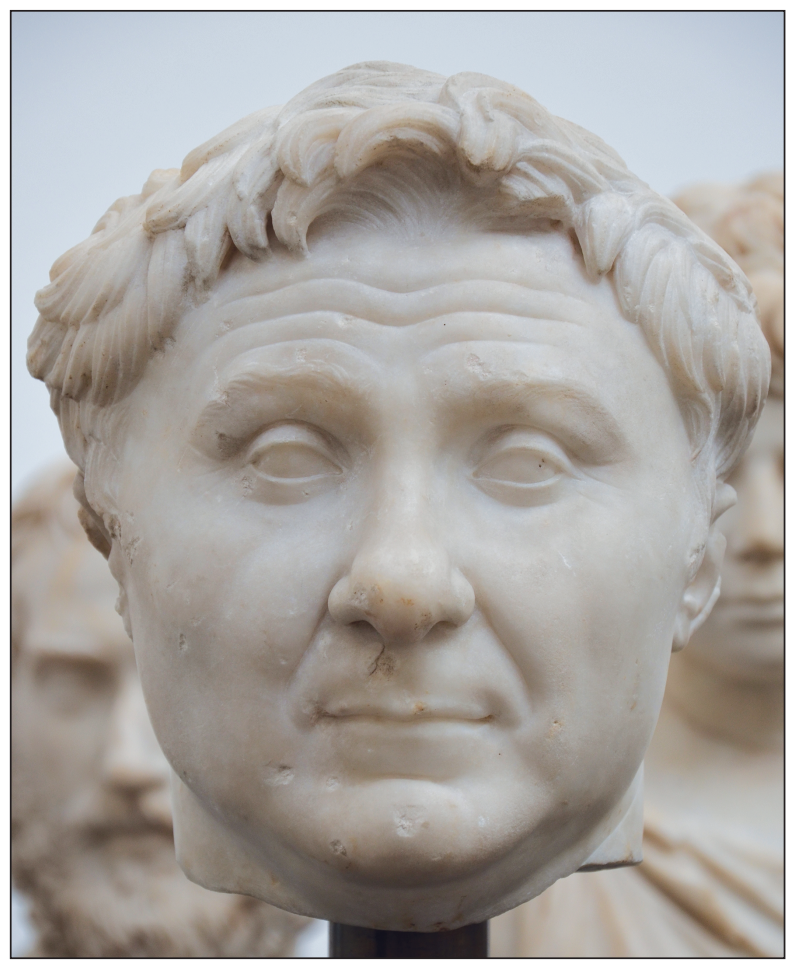

1o. Gnaeus Pompey.

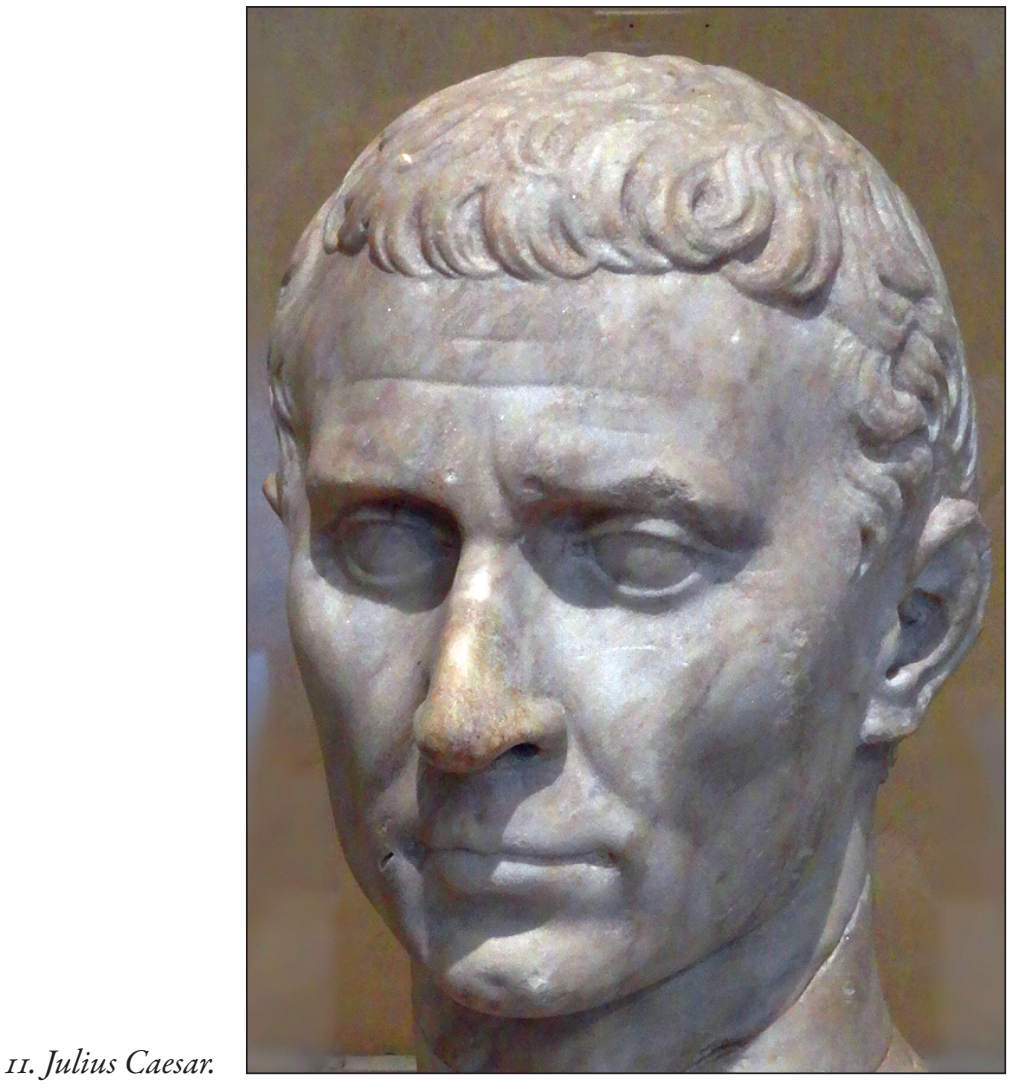




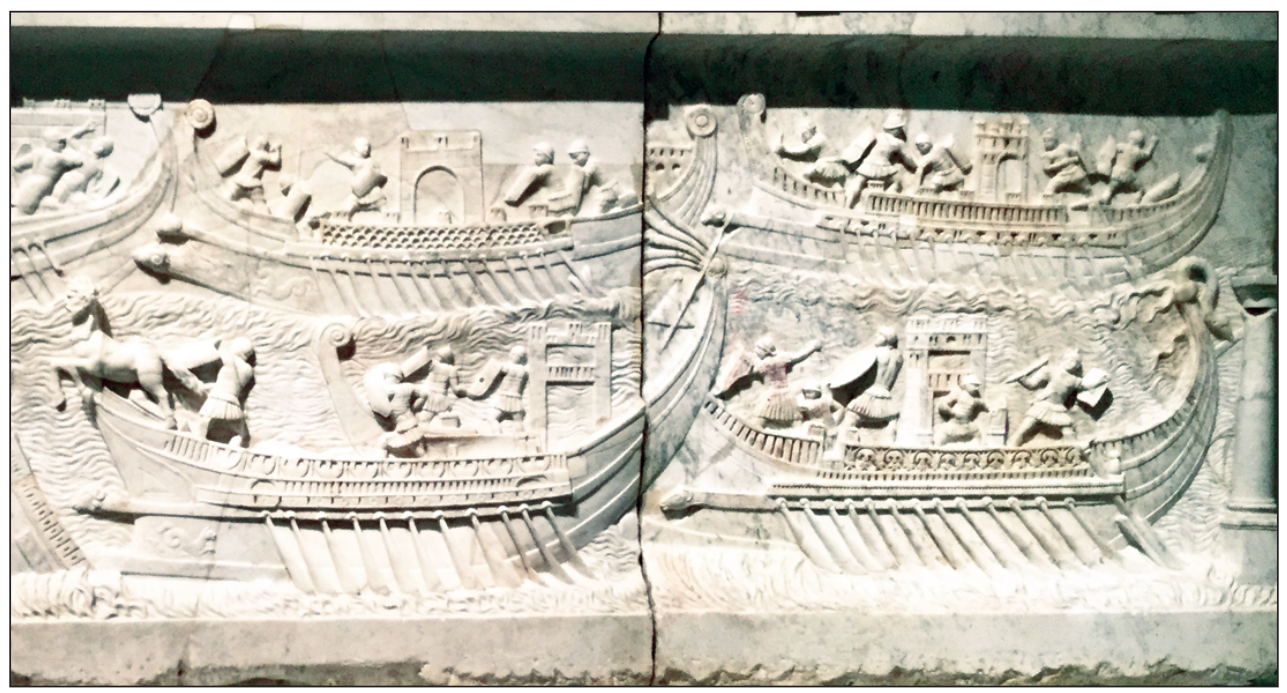

I2. A portion of relief depicting the Battle of Actium from a monument originally constructed at Avellino (p.294).

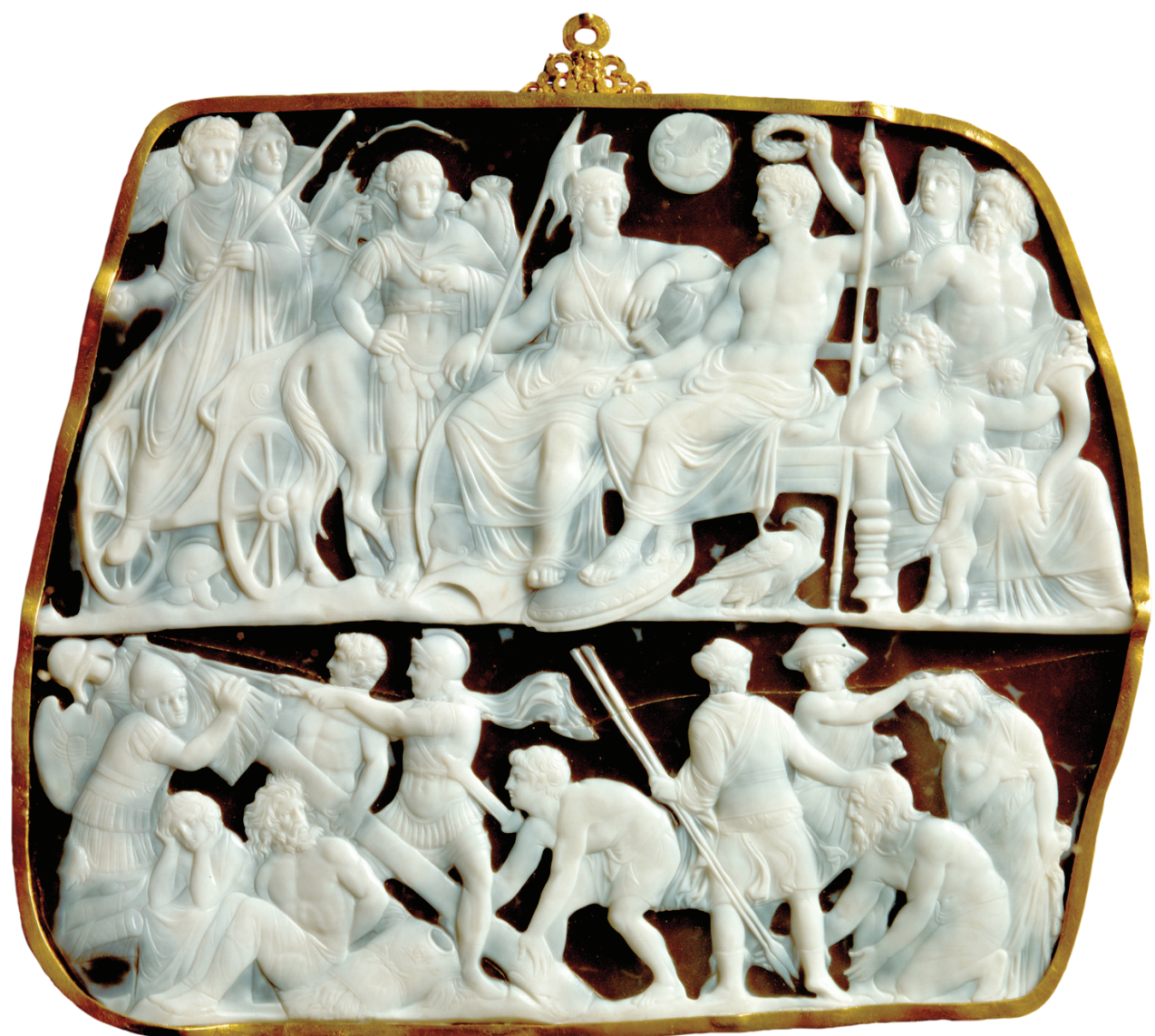

13. The gemma Augustea showing Augustus enthroned in the company of the gods on the top register (it is possible that Roma, who sits next to Augustus has the features of Livia). The lower register shows the erection of a trophy to celebrate a victory over northern peoples. 


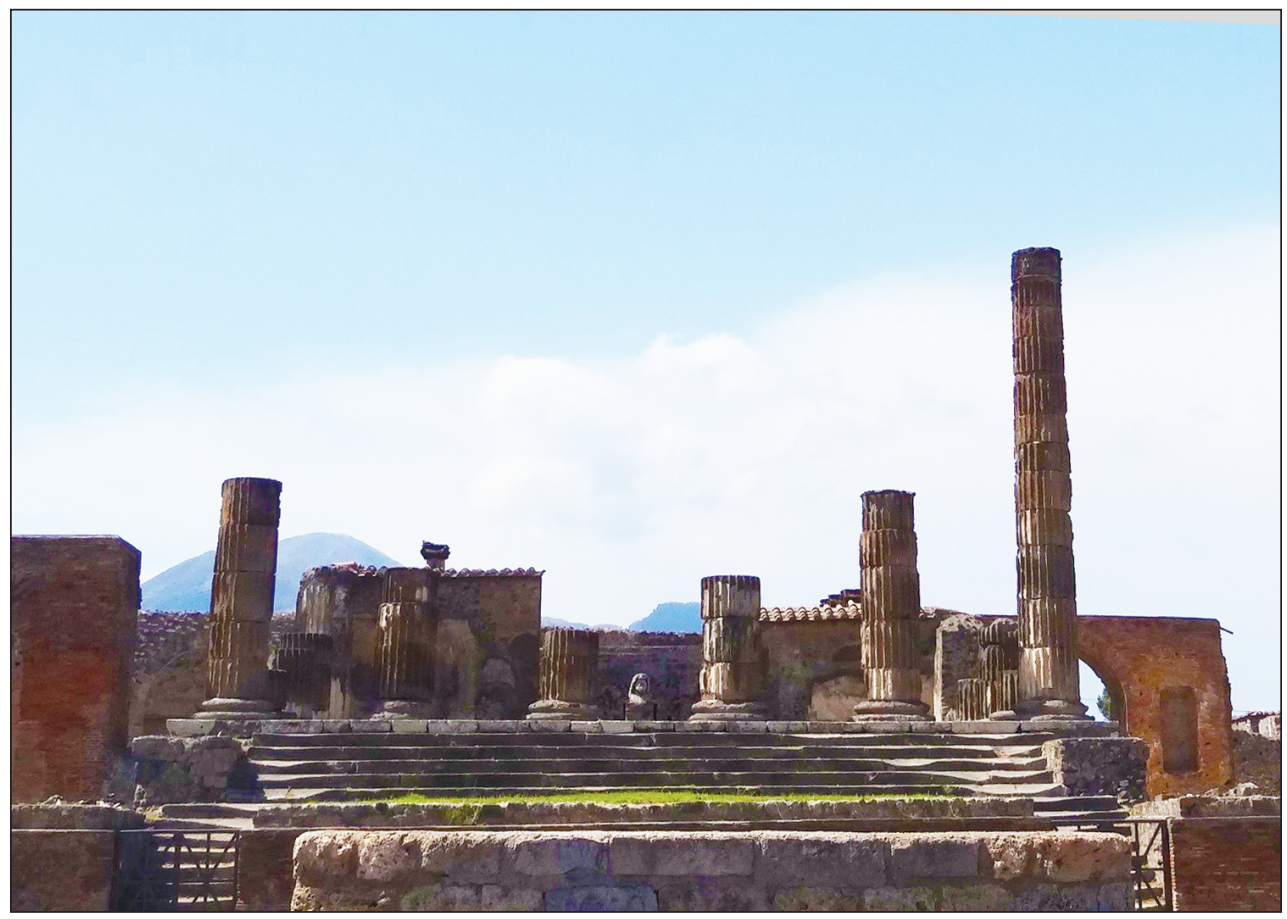

14. The temple of Jupiter at the north end of the forum at Pompeii is emblematic of the transformation and homogenisation of urban space under Roman influence. Vesuvius lurks in the background (p. Is3).

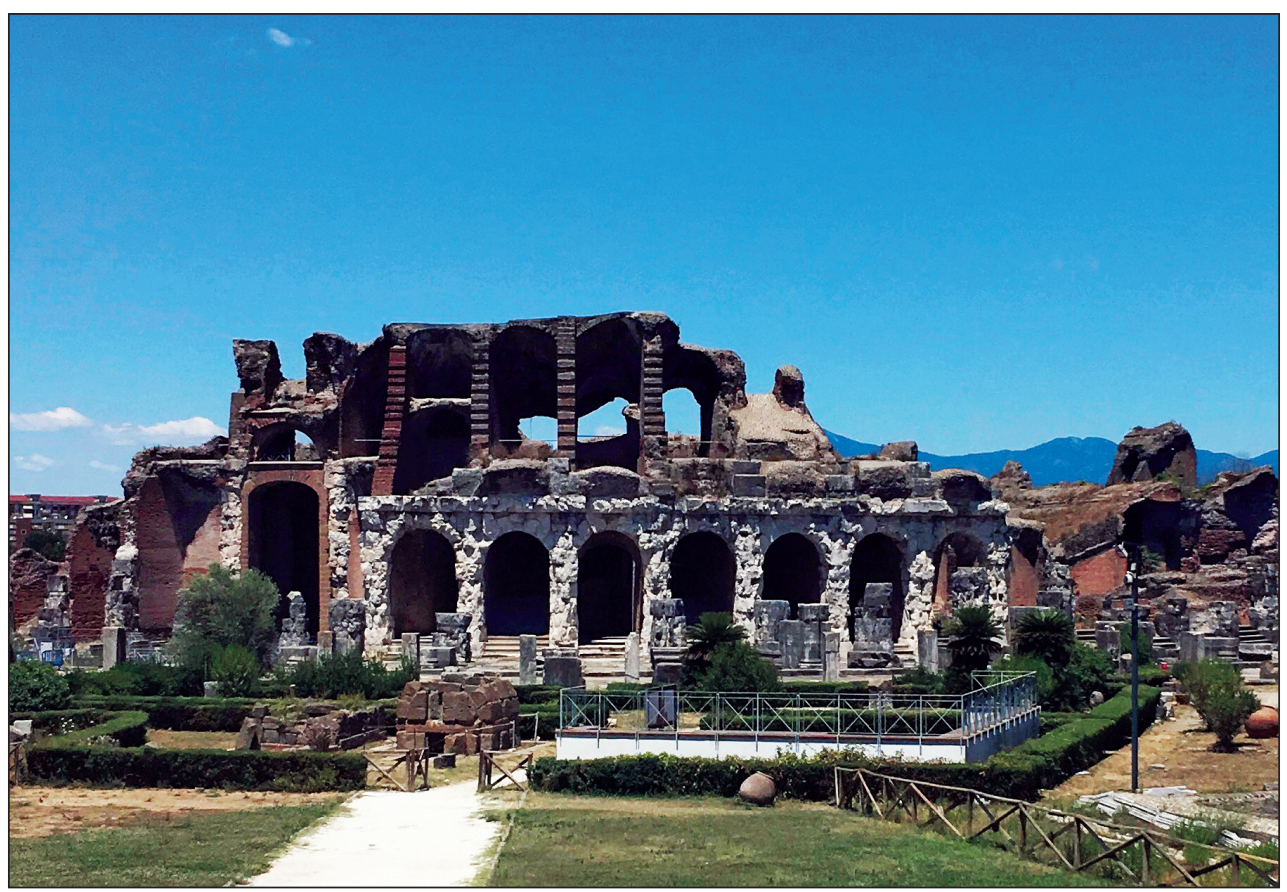

I5. The amphitheatre at Pompeii, modelled on the Colosseum replaced an earlier amphitheatre (where Spartacus would have fought). It is modelled on the Colosseum and is characteristic of building projects in first-second centuries $A D$ (p. 348). 


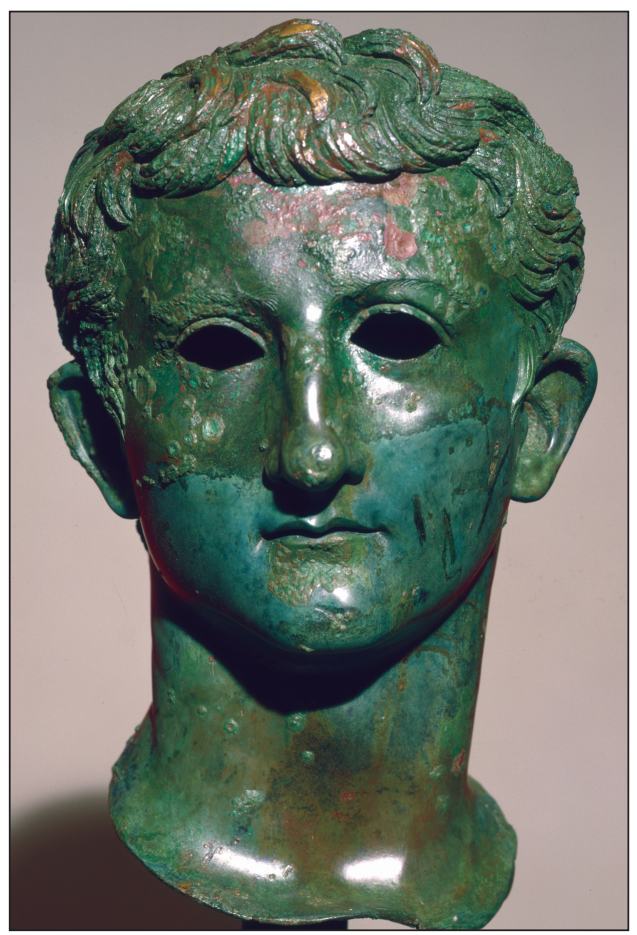

I6. Germanicus Caesar, son of

Drusus and Tiberius' nephew.

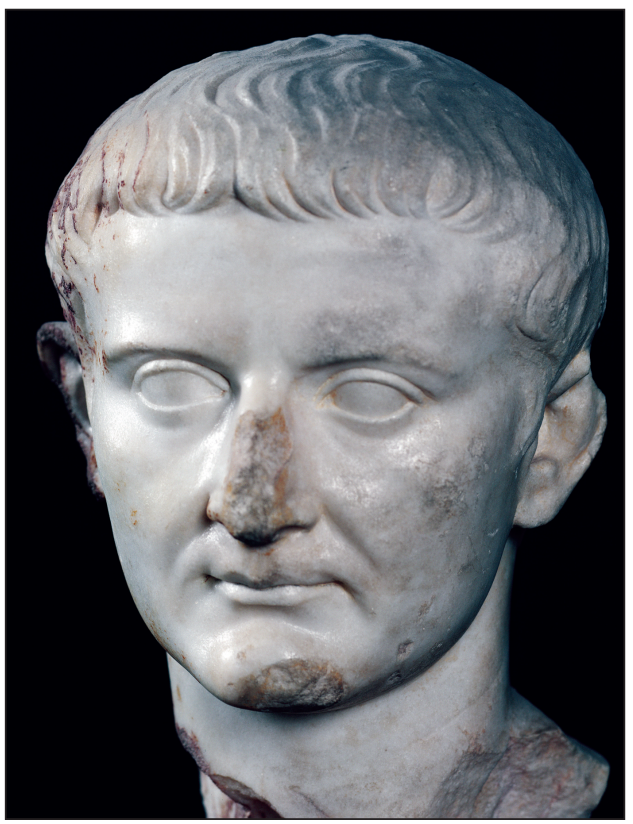

I8. Bust of Tiberius, who, like Augustus, remains perpetually youthful. Suetonius reports that, contrary to the image here, that Tiberius was completely bald.

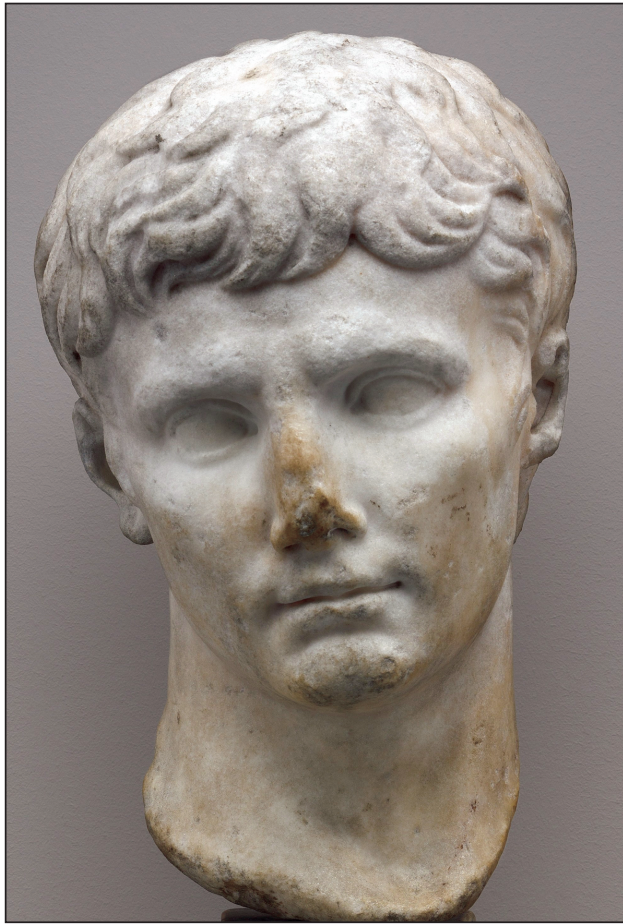

17. Bust of Augustus, who remains perpetually youthful in representations created throughout his reign.

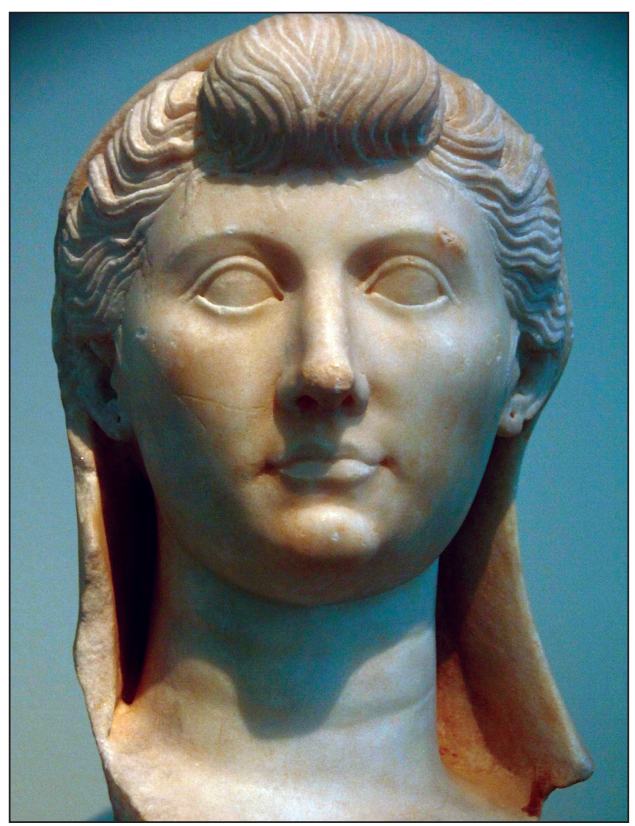

19. Livia, wife of Augustus and a person of great influence in her own right. 


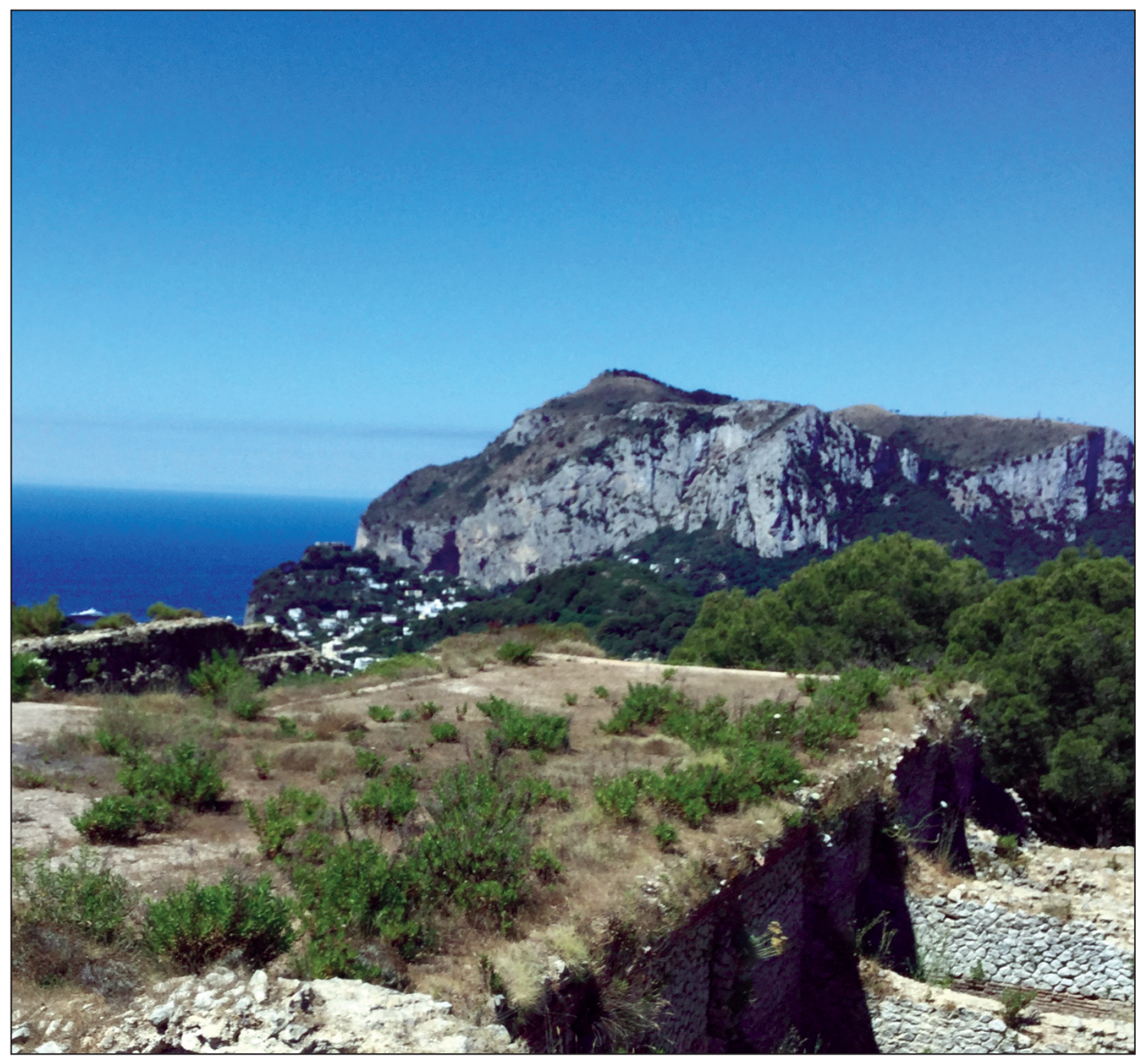

20. The Villa Jovis at Capri was Tiberius' principal residence after his departure from Rome in 27 BC. The site's spectacular natural beauty cannot conceal the fact that the villa is far too small to house the bureaucracy needed to run an empire (p. 337).

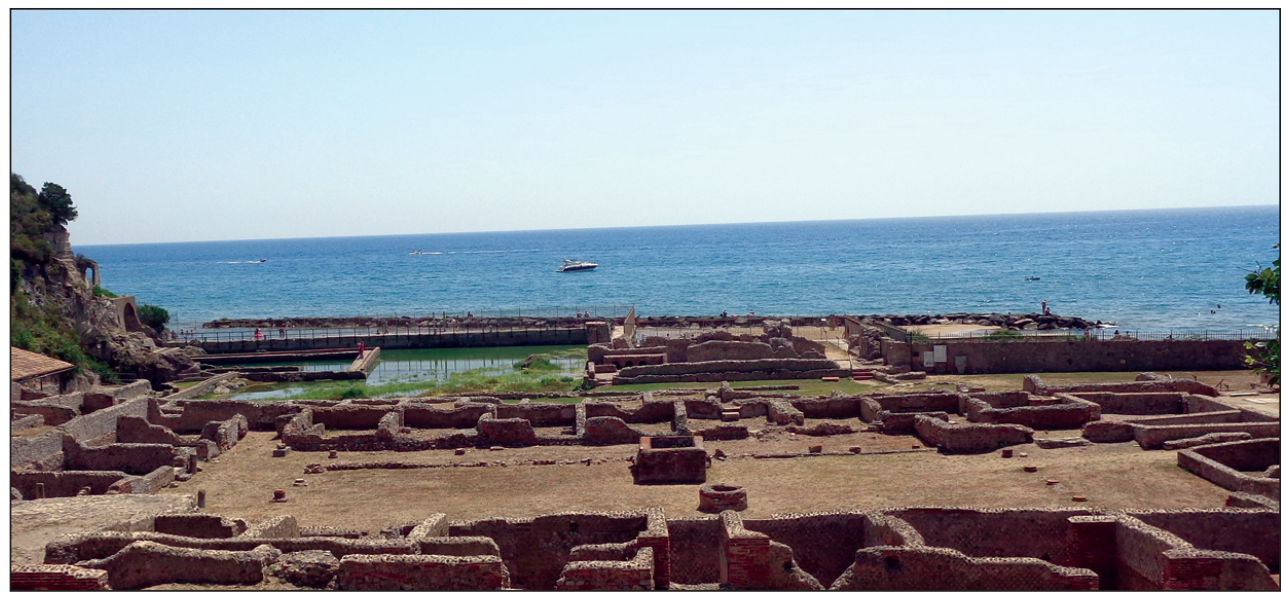

2I. The villa at Sperlonga was another of Tiberius' favorite places, but it too is far too small to house the government of the empire (compare the imperial reception area in Hadrian's palace at Tivoli, $p .383$ ). 


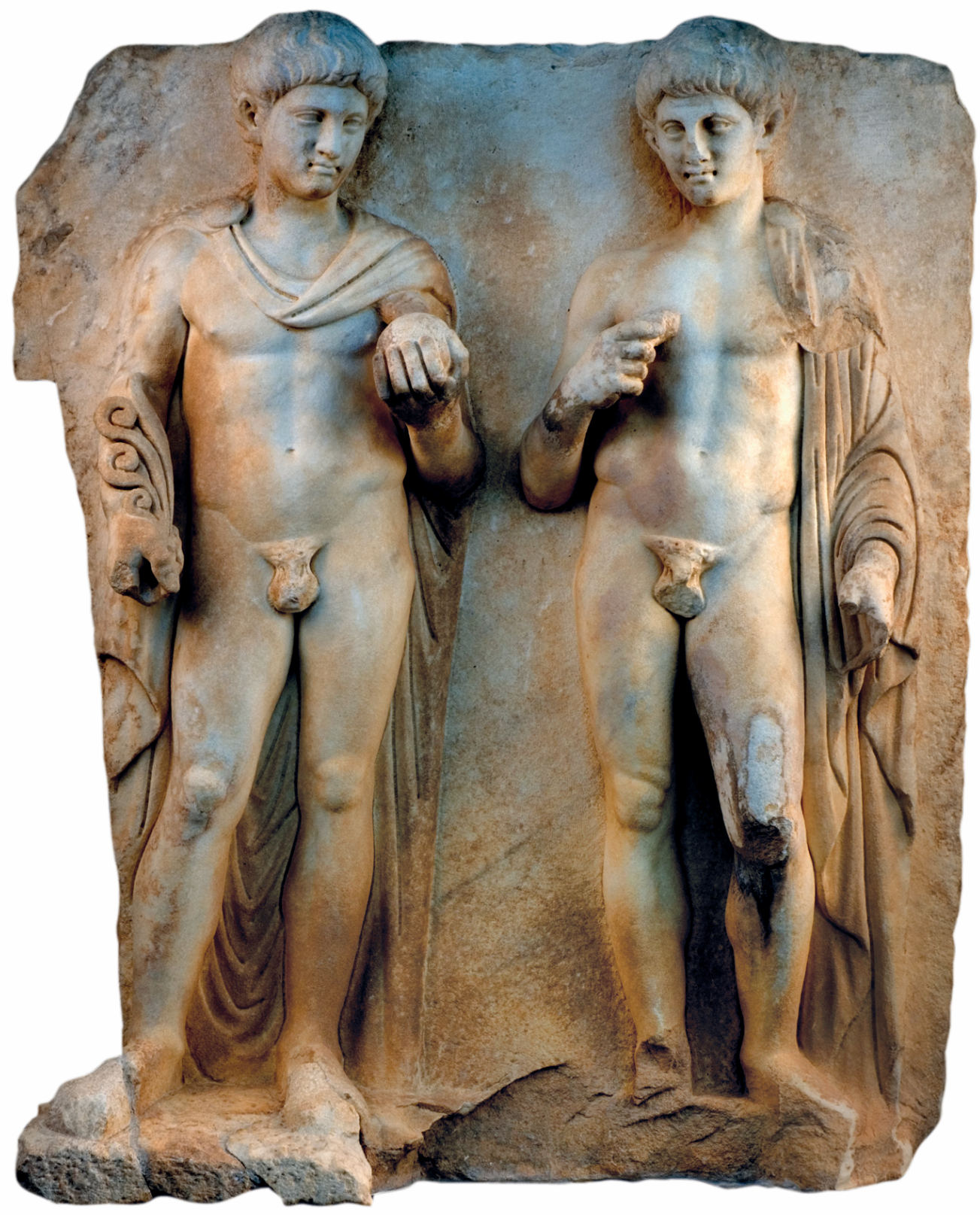

22. Two imperial princes, most likely Nero and Britannicus, from the Sebasteion at Aphrodisias (p. 35I). 


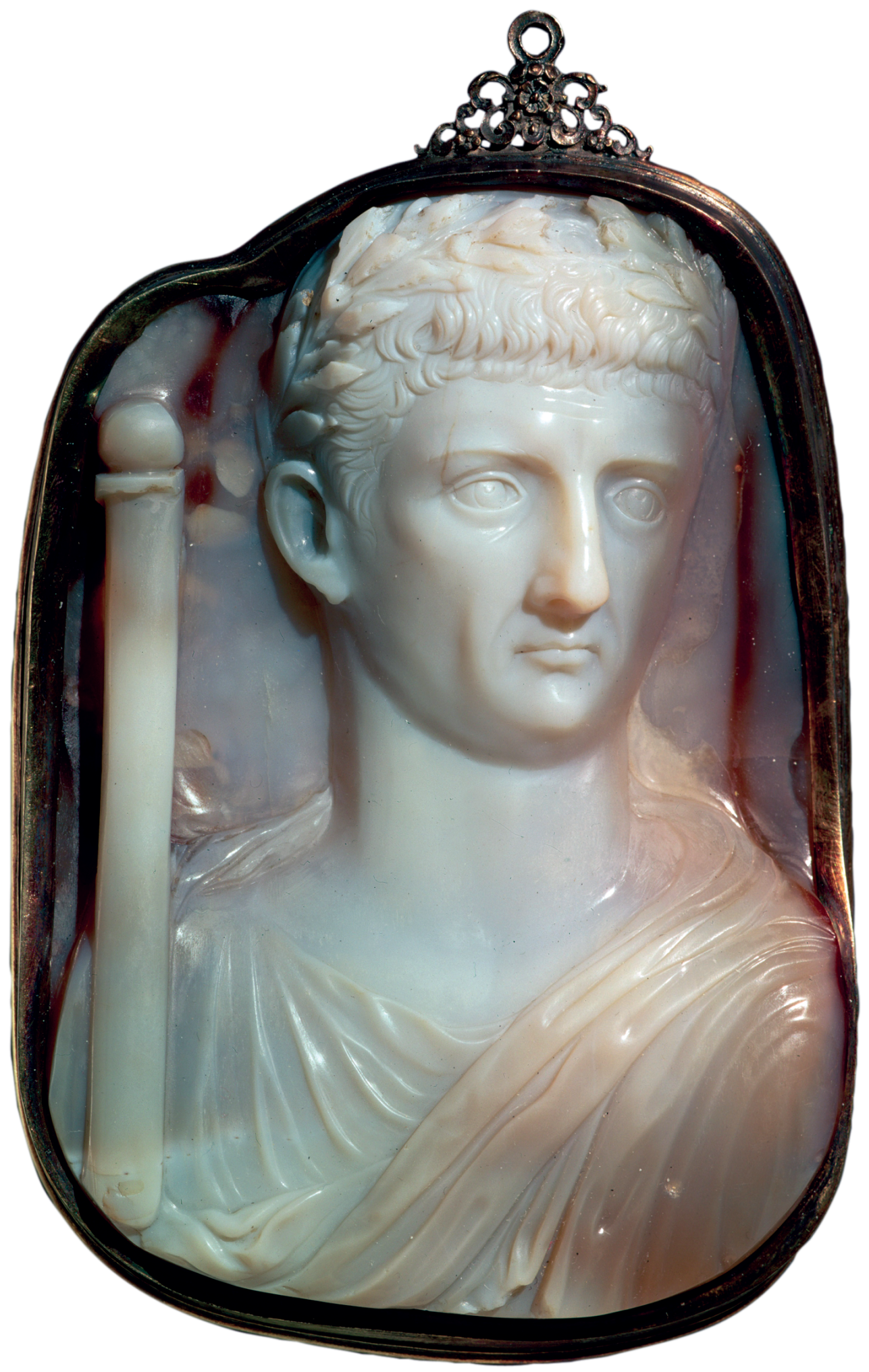

23. Cameo portrait of Claudius. The image echoes that of his brother, Germanicus. 
24. Agrippina the Younger, daughter of Germanicus, wife of Claudius and mother of Nero.

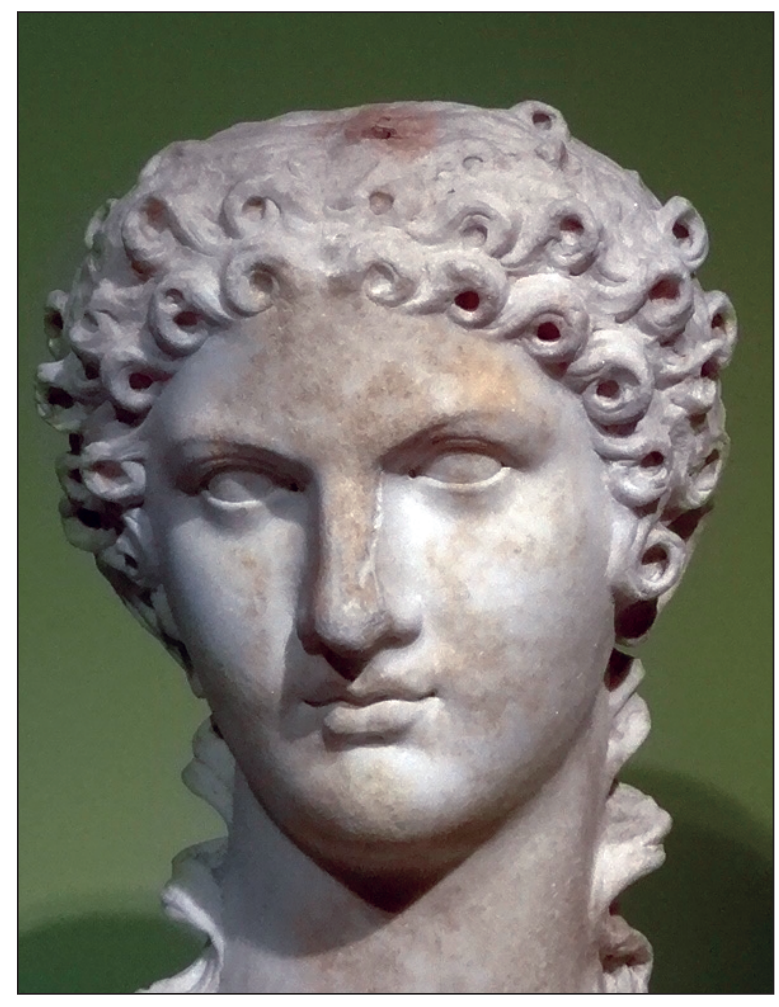

25. Nero, the image is distinctive, stressing his difference from Claudius.

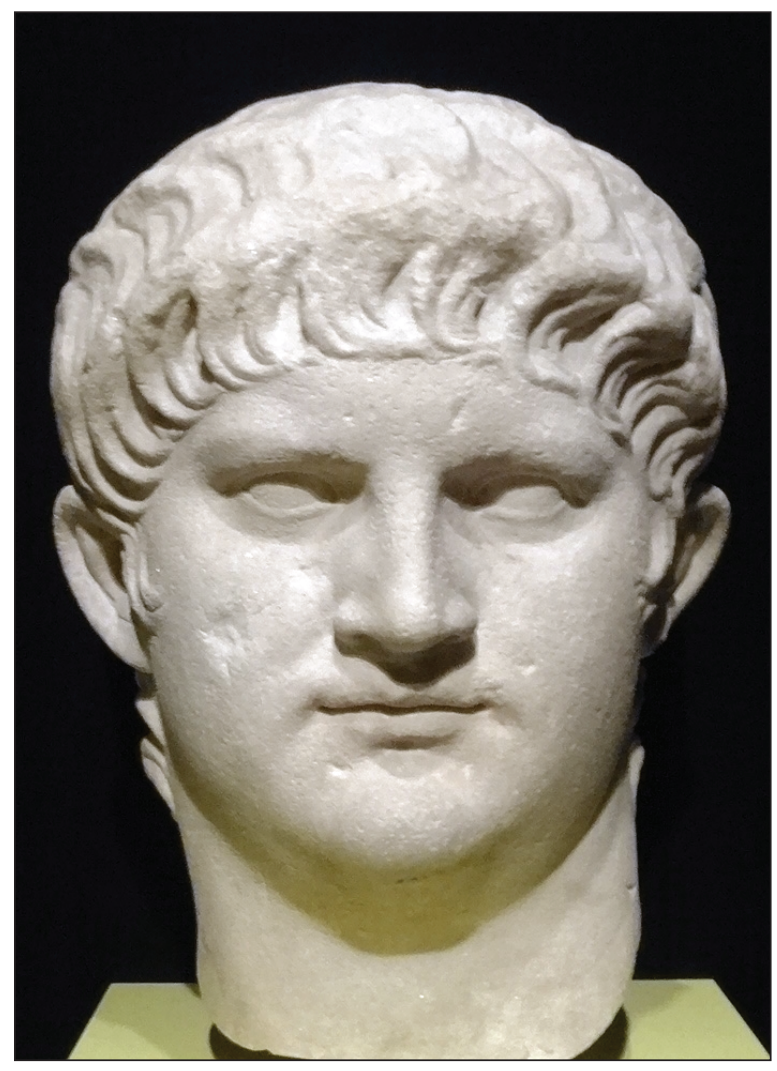




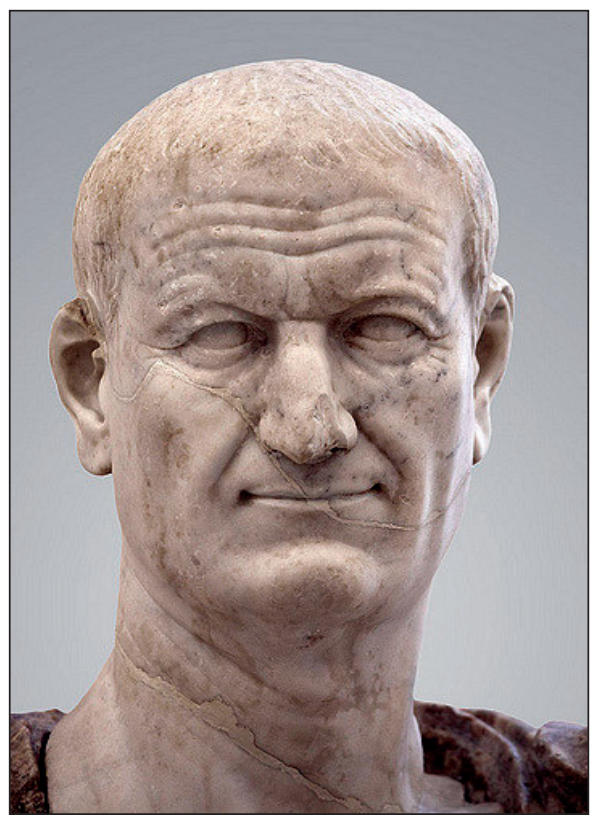

26. Vespasian. The stress on his maturity distinguishes him from Nero.

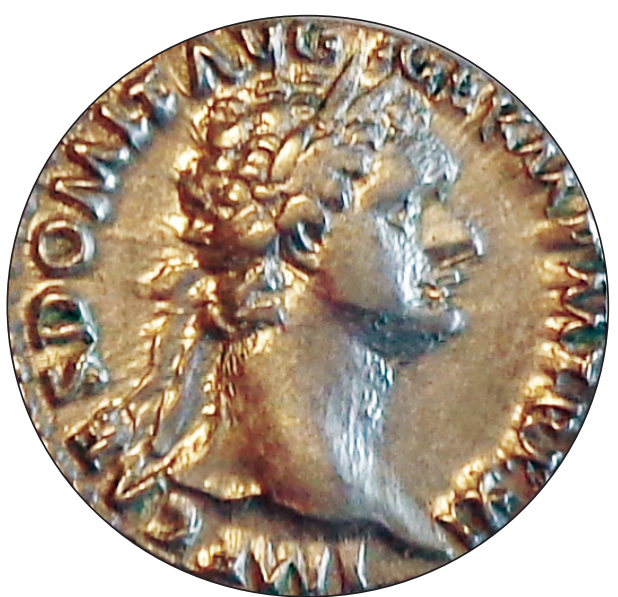

27. Domitian. Like Tiberius, his portraiture shows him with more hair than he possessed in his mature years. Juvenal referred to him as the 'bald Nero.' It also distinguishes him from his father and brother whose public images were virtually identical.

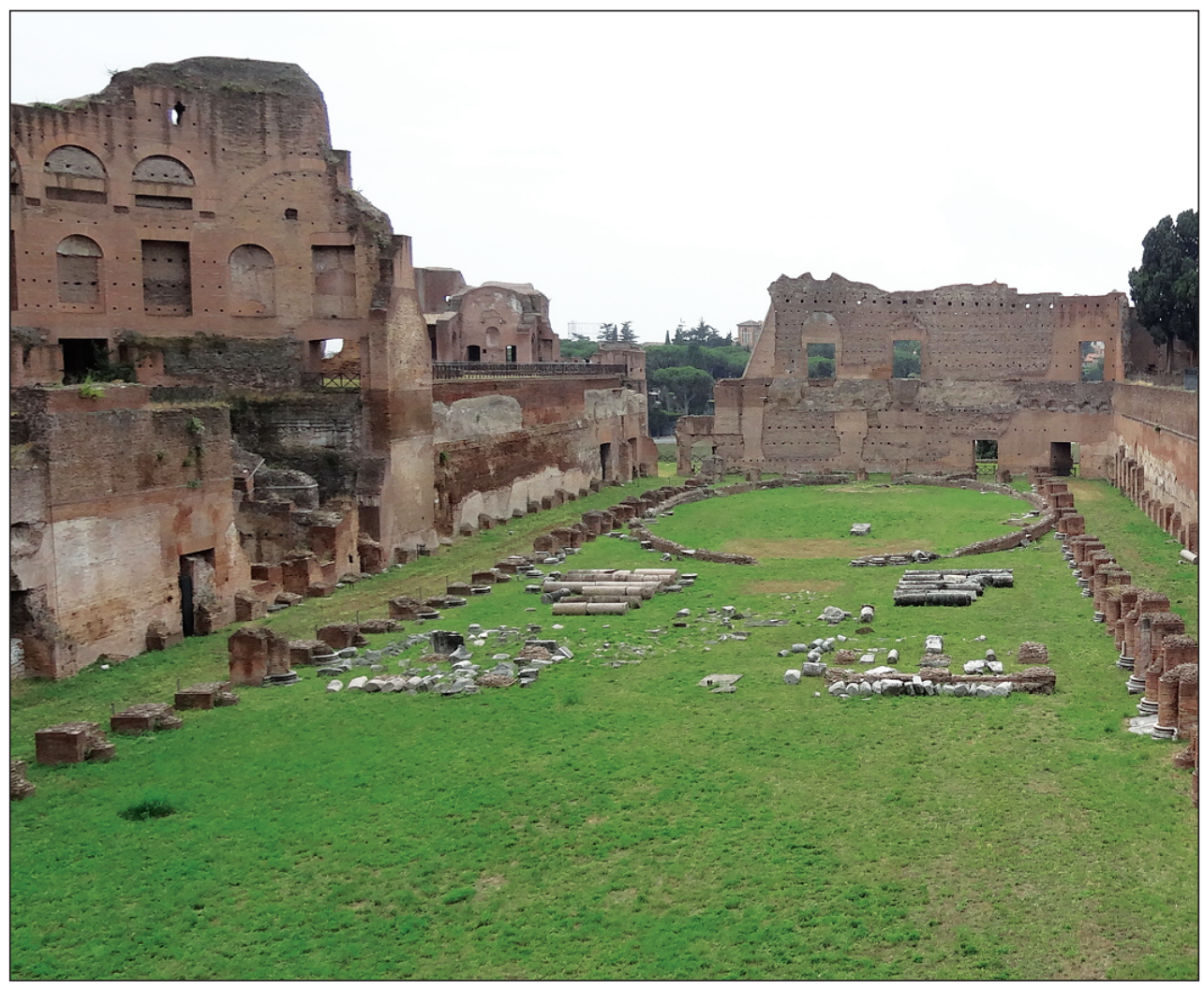

28. Vespasian began the rebuilding of the imperial palace on the Palatine on a much more generous scale, the scene here is of the stadium that was part of the palace. 


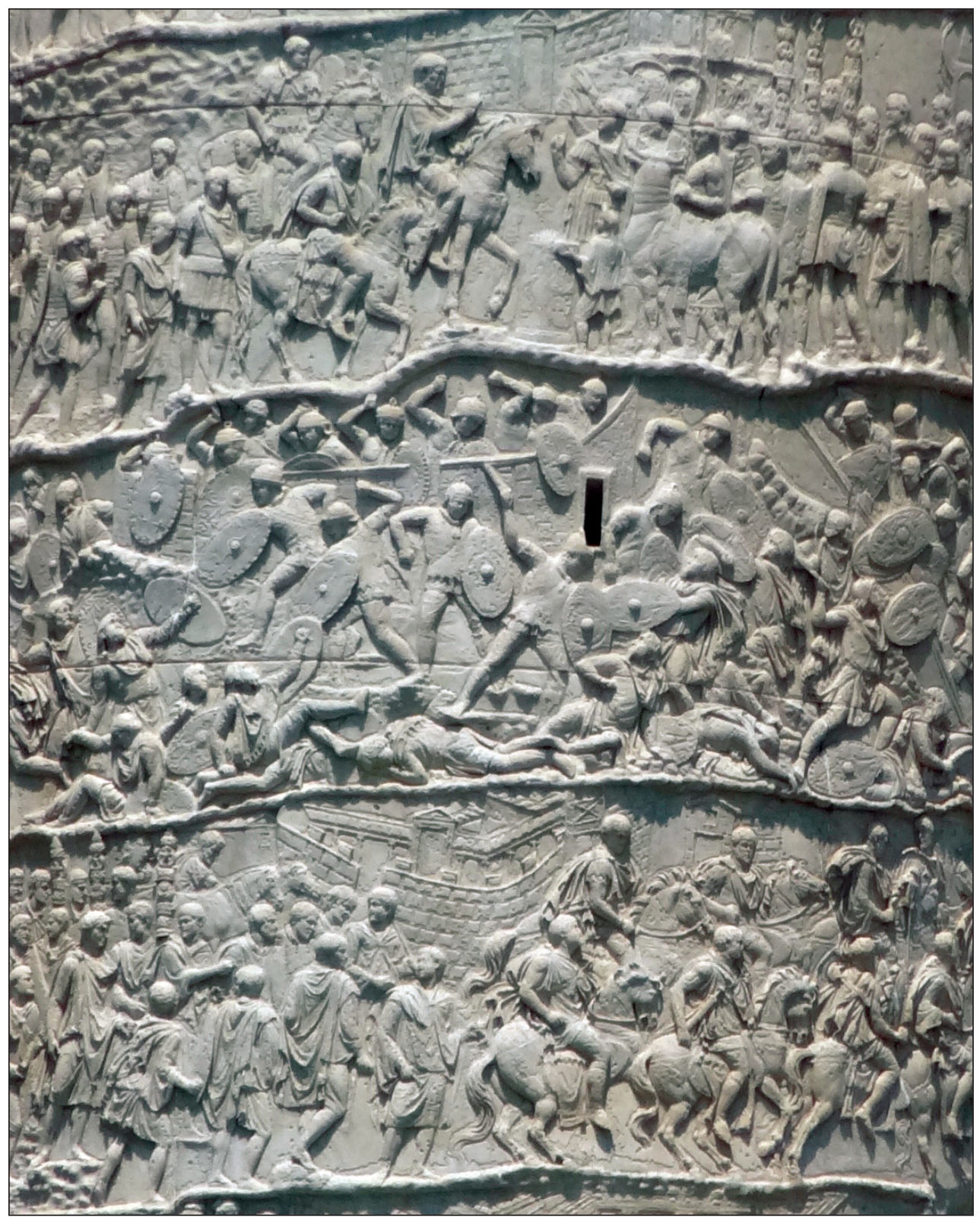

29. Scenes from Trajan's Column, depicting his campaigns in Dacia (p. 393). In addition to slaughtering Dacians, the column suggests the process of incorporating the new area within the empire through its stress on Roman building projects. 


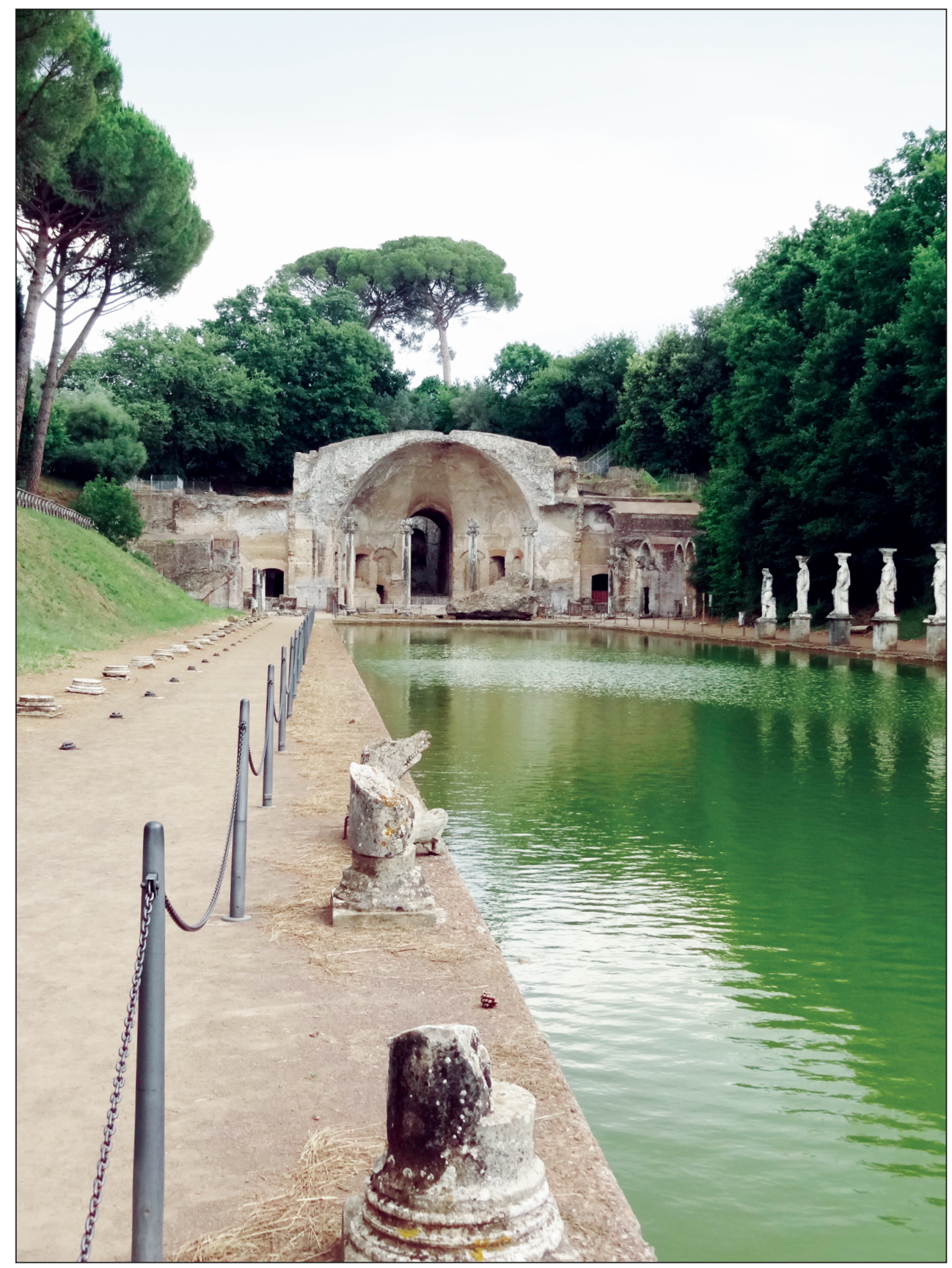

30. The Canopus, a part of Hadrian's palace at Tivoli named for a famous suburb of Alexandria on the western bank at the mouth of the westernmost branch of the Nile Delta (see p. 398). 